\title{
Alternative Technique for Assessing Mathematical Creative Thinking in Geometry based on Information Processing Taxonomy Model
}

\author{
Hevy Risqi Maharani ${ }^{1}$, YL Sukestiyarno ${ }^{2}$, St. Budi Waluya ${ }^{3}$, Mulyono ${ }^{4}$ \\ ${ }^{1}$ Mathematics Education Department, Universitas Islam Sultan Agung, Indonesia \\ ${ }^{2,3,4}$ Mathematics Education Department, Universitas Negeri Semarang, Indonesia \\ Corresponding email: hevyrisqi@unissula.ac.id
}

\begin{abstract}
The main characteristics of information processing taxonomy model consist of retrieving information from external memory and primary and secondary productions of Type A and Type B information. This characteristic becomes the components of different levels of thinking which could be used to confirm and explain the student's creative thinking. This paper describes the development of a geometry test for assessing mathematical creative thinking based on information processing taxonomy model at different hierarchical levels. The instrument development process followed two phases: instrument formation and instrument validation. Instrument formation consists of a literature review, generating items, evaluating proposed items, and a pilot testing draft. Instrument validation used a statistical method to find the indexes of validity, reliability, difficulty, and discrimination of test items. Results showed that the constructed test instrument consists of 5 items. All of the test items were valid and can be used to analyze mathematical creative thinking.
\end{abstract}

Keywords: creative thinking, information processing taxonomy, geometry, assessment

\section{Introduction}

Educational objectives should be seen as policy statements of direction that provide the foundation for the entire educative structure. Regardless of the particular course, we might be thinking of, we should always try to first ensure it has an internally consistent structure. In this regard, an alignment is necessary between objectives, assessment, and instructional strategies. While objectives state what we want the learner to acquire, the assessment allows the educator to check to what extent the learner meets the objectives. It is through instructional strategies that the educator provides for the teaching-learning process meant to guide the learner towards the above-mentioned objectives (Bonaci, Mustata, \& Ienciu, 2013).

Mathematical learning is necessary designed so that it can develop student's creative thinking (Alfian, Dwijanto, \& Sunarmi, 2017; Arifah, Rochmad, \& Sugiman, 2016; Hapsari, Supriyono, \& Hendikawati, 2015; Konita, Sugiarto, \& Rochmad, 2017; Utami, Masrukan, \& Arifudin, 2014; Warda, Mashuri, \& Amidi, 2017; Wijaya, Rochmad, \& Agoestanto, 2016). Creative thinking becomes very important to be given to someone since his early age (Nuha, Waluya, \& Junaedi, 2018). The result of a study indicates that it is possible to teach thinking skills and thinking skills instruction should begin in pre-school years (Akınoğlu \& Karsantik, 2016). Hence developing the quality of creative thinking has always been one of the main goals of education. It can be done if we already know the extent of the creative thinking ability of students today with an appropriate assessment.

Use of the taxonomy can help one gain a perspective on the emphasis given to certain behaviors by a particular set of educational plans. One technique that has been widely used to evaluate a quality of a student's output is Bloom's taxonomy developed in 1956. The major idea of the Bloom's taxonomy is that what educators want students to know (encompassed in statements of educational objectives) can be arranged in a hierarchy from less to more complex. The levels are understood to be successive so that one level must be mastered before the next level can be reached (Huitt, 2011). The original levels by Bloom were ordered as follows: Knowledge, Comprehension, Application, Analysis, Synthesis, and Evaluation (Bloom, Engelhart, Furst, Hill, \& Krathwohl, 1956; Bonaci et al., 2013; Huitt, 2011; IACBE, 2014; Munzenmaier \& Rubin, 2013).

Another technique used to assess the quality of students' responses is the SOLO (Structure of the Observed Learning Outcome) taxonomy developed by Biggs and Collis in 1982. The SOLO taxonomy is used to classify the quality of students' responses to a problem into five different and hierarchical levels are pre-structural, uni-structural, multi-structural, relational, and extended abstract (Biggs \& Collis, 1982; O’Neill \& Murphy, 2010; Potter \& 
Kustra, 2012). The SOLO Taxonomy was developed by analyzing the structure of student responses to assessment tasks in response to a given body of information or knowledge and identifying the type of thinking exhibited by extended written responses. This taxonomy is suitable for measuring learning outcomes for all subjects, levels, and for all types of tasks (Biggs \& Collis, 1982; Hattie \& Brown, 2004; O’Neill \& Murphy, 2010).

Although both taxonomies (Bloom and SOLO) have proven useful in assessing students' abilities, these two taxonomies have some disadvantages in their implementation. The Bloom and SOLO taxonomies are useful for building an item to get students' responses at different levels. These two taxonomies cannot provide a precise explanation of how the cognitive processes in solving the problem to find a solution. Therefore, it is necessary to use an appropriate model in assessing mathematical abilities. The model is called the information processing taxonomy.

The information processing taxonomy model consists of two general features (Fong, 1994, 1995): (a) a set of information processing features such as the external source (ES), shortterm memory (STM) or working memory (WM) and long-term memory (LTM), and (b) an operating system comprising perception through stimulus, retrieving information from ES, and operations based on primary and secondary productions. The model is described in Table 1 in term of the hierarchical levels and the different levels of processing information.

Table 1. Information Processing Taxonomy Model

\begin{tabular}{cc}
\hline Level & $\begin{array}{c}\text { Characteristic Features \& Operating } \\
\text { Systems }\end{array}$ \\
\hline One & $\begin{array}{c}\text { ES, STM/WM; Perception through stimulus, } \\
\text { retrieving information from ES. } \\
\text { ES, STM/WM, LTM (Type A Information); } \\
\text { Perception through stimulus, retrieving } \\
\text { information from ES and primary production } \\
\text { system. }\end{array}$ \\
Three & $\begin{array}{c}\text { ES, STM/WM, LTM (Type A \& B } \\
\text { retrieving information from ES and primary } \\
\text { production system. }\end{array}$ \\
& $\begin{array}{c}\text { ES, STM/WM, LTM (Type A Information); } \\
\text { Perception through stimulus, retrieving } \\
\text { Four }\end{array}$ \\
& $\begin{array}{c}\text { information from ES, primary \& secondary } \\
\text { production system. }\end{array}$ \\
Five & $\begin{array}{c}\text { Information); Perception through stimulus, } \\
\text { retrieving information from ES, primary \& } \\
\text { secondary production system. }\end{array}$ \\
\hline Source: (Fong, 1994)
\end{tabular}

An external source (ES) refers to the data or information obtained from the problem or a question asked. Each question is viewed as consisting of pieces of information which could be in the form of facts, numerals, procedures, etc. All information, whether it comes from the external sources or the long-term memory, is to be processed in the short-term memory or working memory (STM/WM). This part of the human brain has a limited capacity and is the only process to hold certain chunks of information at one time. There are two types of information that can be stored in the long-term memory. Information which is related to the recent content area of study and information which is often rehearsed is classified as type A information. Information on related topics is classified as type B information. Type A information is assumed to be readily remembered or retrieved by students as compared to type B information (Fong, 1994).

So, this paper wants to describe the development of a geometry test for assessing mathematical creative thinking based on information processing taxonomy model at different hierarchical levels.

\section{Methods}

The instrument development process followed two phases: instrument formation and instrument validation (Beyers, 2011). Phase 1 (instrument formation) had four components: 1) performing a review of relevant literature, 2) generating items, and 3) evaluating of proposed items by colleagues in mathematics education, as well as, 4) pilot testing the draft of the instrument. Phase 2 (instrument validation) used statistical methods to find the indexes of validity, reliability, difficulty, and discrimination of test items. Population in this research was all students of the $8^{\text {th }}$ grade in the lower secondary school of 18 Semarang. There are 8 classes and one class was selected as the pilot testing draft of instruments that consist of 32 students. The instruments that have been constructed will be evaluated by experts in the field of mathematics education, consist of 6 persons. After evaluating, a pilot testing draft instrument will be done and the result will be validated using the statistical methods to find the indexes of validity, reliability, difficulty, and discrimination of test items. 


\section{Results and Discussion}

The test instrument that will be used to analyze the creative thinking process of students in solving geometry problems is constructed based on information processing taxonomy model consist of 5 items. The components of different levels of thinking in information processing taxonomy model which could be used to confirm and describe the student's creative thinking process. The first item in the geometry test as the level one being the least difficult and the last item as the level five being the most difficult.

The instruments that have been constructed will be evaluated by experts in the field of mathematics education, consist of 6 persons. The results of evaluating experts get the average score 4,38 from 5 , included in a very good category. It means the instrument can be used and can be continued to pilot testing draft of the instrument. One intact class of 32 students were selected for the pilot testing draft.

Examples are shown to describe how the information processing taxonomy model could be used to construct test item in geometry at different levels on the basis of these features. This study used the solid theme as the content area of study. Example 1 is shown the test item in the second level based on the hierarchy level of information processing taxonomy model.

\section{Example 1}

The roof of a building has a square pyramid shape is $18 \mathrm{~m} \times 18 \mathrm{~m}$. The high of the roof is 9 $m$. Find the volume of air that contained in the building!

Figure 1 shows that two sources of information are operated at the STM level. (1'), the roof of a building has a square pyramid shape, $s=18 \mathrm{~m}, h=9 \mathrm{~m}$, and (2'), find the volume of air that contained in the building, are pieces of information retrieved from the ES. Information (3'), the volume of pyramid formula, is retrieved from the LTM. They are operated at the STM to produce (4), 972.

Figure 1. Representation of Creative Thinking Process for Solving Example 1

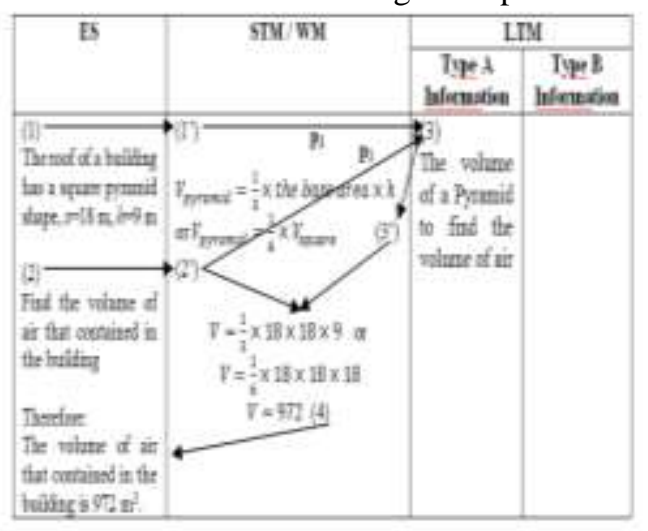

Example 2 shows the test item on the third level based on the hierarchy level of information processing taxonomy model.

\section{Example 2}

Some of the unit cubes are arranged into a cuboid of $5 \times 3 \times 4$ volume units. The unit cubes are not added or reduced will be formed into another cuboid. Find all possible new cuboid sizes that can be created!

Figure 2. Representation of Creative Thinking Process for Solving Example 2

\begin{tabular}{|c|c|c|c|}
\hline \multirow[t]{2}{*}{ B } & \multirow[t]{2}{*}{ 5TM/WY } & \multicolumn{2}{|c|}{ IIM } \\
\hline & & $\begin{array}{c}\text { Tyge A } \\
\text { lafirmatia }\end{array}$ & $\begin{array}{c}\text { Type } 3 \\
\text { larasia }\end{array}$ \\
\hline 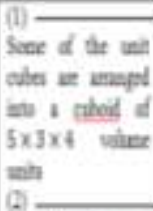 & 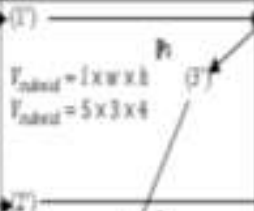 & Voluse di & \\
\hline 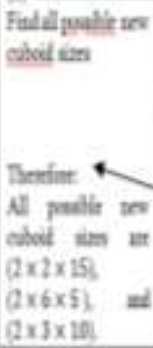 & 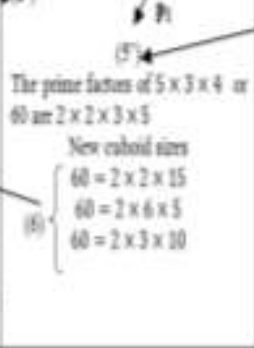 & & 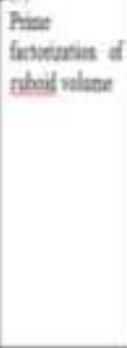 \\
\hline
\end{tabular}

In example 2 question, the topic being assessed is the solid theme. Hence any skills related to the solid theme are classified as type A information. Notice that in Figure 2, the volume of a cuboid is classified as type A information. The statement "prime factorization of cuboid volume" which is not a skill directly related to the topic of the solid theme is classified as type B information. These pieces of information described above are retrieved from the LTM.

Example 3 is shown the test item in the five-level based on the hierarchy level of information processing taxonomy model.

\section{Example 3}

The volume of the cuboid-shaped swimming pool is $64 \mathrm{~m}^{3}$. If the ratio of the length, width, and height is 4:2:1. Find the length, width, and height of the swimming pool!

In Example 3, both the primary and secondary production of information were observed to elicit information from the secondary sources (Figure 3). The primary production is using the method to find the 
length, width, and height by applying concept "volume of swimming pool = volume of cuboid", whereas the secondary production is the technique to substitution the value of $x$ to the ratio of the length, width, and height.

Figure 3. Representation of Creative Thinking Process for Solving Example 3

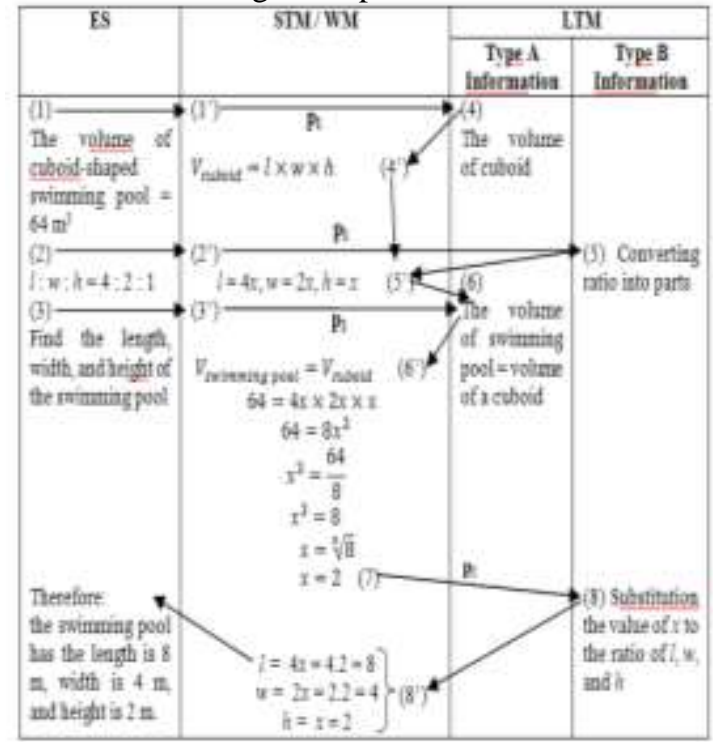

There were four stages in instrument validation phase. The first stage was finding the validity of the test items. The validity has been analyzed by using product moment correlation formula. The test items considered valid if $r_{x y}>$ $r_{\text {table }}$. The result of $r_{\text {table }}=0,349$ with $N=$ 32 and $\propto=5 \%$. The second stage was finding the reliability test. The reliability has been analyzed by calculating the value of $r_{11}$. If $r_{11}>$ $r_{\text {table }}$ then the test items were said to be reliable. The third stage was finding the item difficulty index by dividing average score of each item with the maximum score of each item. The last stage was finding the discrimination index. The result of all analysis can be seen in Table 2 .

Table 2. Indexes of Validity, Reliability, Difficulty, and Discrimination for Test Items

\begin{tabular}{|c|c|c|c|c|}
\hline No & $\begin{array}{c}\text { Validi } \\
\text { ty }\end{array}$ & $\begin{array}{c}\text { Reliabi } \\
\text { lity }\end{array}$ & Difficulty & $\begin{array}{c}\text { Discrimi } \\
\text { nation }\end{array}$ \\
\hline 1 & $\begin{array}{c}0,763 \\
\text { (valid) }\end{array}$ & & $\begin{array}{c}0,82 \\
\text { (easy) }\end{array}$ & $\begin{array}{c}0,50 \\
\text { (good) }\end{array}$ \\
\hline 2 & $\begin{array}{c}0,804 \\
\text { (valid) }\end{array}$ & & $\begin{array}{c}0,65 \\
\text { (medium) }\end{array}$ & $\begin{array}{c}0,44 \\
\text { (good) }\end{array}$ \\
\hline 3 & $\begin{array}{c}0,772 \\
\text { (valid) }\end{array}$ & $\begin{array}{l}0,793 \\
\text { (reliabl }\end{array}$ & $\begin{array}{c}0,64 \\
\text { (medium) }\end{array}$ & $\begin{array}{c}0,44 \\
\text { (good) }\end{array}$ \\
\hline 4 & $\begin{array}{c}0,633 \\
\text { (valid) }\end{array}$ & e) & $\begin{array}{c}0,62 \\
\text { (medium) }\end{array}$ & $\begin{array}{c}0,50 \\
\text { (good) }\end{array}$ \\
\hline 5 & $\begin{array}{c}0,734 \\
\text { (valid) }\end{array}$ & & $\begin{array}{c}0,52 \\
\text { (medium) }\end{array}$ & $\begin{array}{c}0,58 \\
\text { (good) }\end{array}$ \\
\hline
\end{tabular}

Based on the data in Table 2, it can be concluded that all of the test items can be used as an instrument in this study. It means that the instrument can be used to assess and describe mathematical creative thinking process of students at different hierarchical levels of information processing taxonomy model. The test items difficulty index demonstrated that the items difficulty index increases from item number 1 to item number 5 . The hierarchical pattern seems to conform to the hypothesised of information processing taxonomy model This is appropriate with Fong (1994, 1995), instrument test based on information processing taxonomy model could determine their levels of thinking in terms of the processes of mathematical knowledge underlying some specifics features, such as the primary and secondary production of information and type $\mathrm{A}$ and $\mathrm{B}$ information retrieved from the LTM.

\section{Conclusion}

The information processing taxonomy model could be used to construct mathematical creative thinking test items in geometry at different levels based on existing characteristics. There were 5 items that have been constructed in this study. All of the test items have followed the instrument development process. The results of instrument validation showed that all of the items were valid and can be used to analyze mathematical creative thinking. The information processing taxonomy model also has implication for the teaching and learning of mathematics. Using this model, mathematics problems can be classified into several levels of thinking based on specific characteristics in solving problems. Thus, further research in teaching and learning of mathematics may be able to apply these characteristics of the information processing taxonomy model to analyze the mathematical creative thinking process

\section{References}

Akınoğlu, O., \& Karsantik, Y. (2016). PreService Teachers' Opinions on Teaching Thinking Skills. International Journal of Instruction, $\quad 9(2)$, 61-76. https://doi.org/10.12973/iji.2016.925a

Alfian, M. H., Dwijanto, \& Sunarmi. (2017). Effectiveness of Probing-Prompting Learning Models with Scaffolding Strategy to Mathematics Creative Thinking Ability and Enthusiasm. Unnes Journal of Mathematics Education, 6(2), 249-257. https://doi.org/10.15294/ujme.v6i2.17172

Arifah, Y. N., Rochmad, \& Sugiman. (2016). 
Keefektifan Model Pembelajaran CORE Berbantuan Strategi Studi Kasus terhadap Kemampuan Berpikir Kreatif Siswa SMP. Unnes Journal of Mathematics Education, 5(2), 124-130. Retrieved from http://journal.unnes.ac.id/sju/index.php/ujm e

Beyers, J. (2011). Development and Evaluation of an Instrument to Assess Prospective Teachers 'Dispositions with Respect to Mathematics. International Journal of Business and Social Science, 2(16), 20-32. Retrieved from www.ijbssnet.com

Biggs, J. B., \& Collis, K. F. (1982). Evaluating the Quality of Learning. In The SOLO TAxonomy (Structure of the Observed Learning Outcome). New York: Academic Press.

Bloom, B. S., Engelhart, M. D., Furst, E. J., Hill, W. H., \& Krathwohl, D. R. (1956). The Classification of Educational Goal. In TAXONOMY OF EDUCATIONAL OBJECTIVE (pp. 1-201). New York: David McKay Company Inc.

Bonaci, C. G., Mustata, R. V, \& Ienciu, A. (2013). Revisiting Bloom's Taxonomy of Educational Objectives. The Macrotheme Review A Multidisciplinary Journal of Global Macro Trends, 2(2), 1-9.

Fong, H. (1994). Information Processing Taxonomy (IPT): An Alternative Technique for Assessing Mathematical Problem-Solving. Singapore Journal of Education, 14(1), 31-45.

Fong, H. (1995). Children's Productive Thinking in Solving a Ratio and Proportion Problem. Singapore Journal of Education, 14(1), 31-45.

Hapsari, D. T., Supriyono, \& Hendikawati, P. (2015). Keefektifan Model Pembelajaran Missouri Mathematics Project Berbantuan Media POMAT terhadap Kemampuan Berpikir Kreatif Matematis Siswa Kelas VII Materi Segitiga. Unnes Journal of Mathematics Education, 4(3), 251-256. Retrieved from http://journal.unnes.ac.id/sju/index.php/ujm e

Hattie, J. A. C., \& Brown, G. T. L. (2004). COGNITIVE PROCESSES in asTTle: The SOLO TAXONOMY. New Zealand.

Huitt, W. (2011). Bloom et al.' s Taxonomy of the Cognitive Domain. In Educational Psychology Interactive (pp. 1-4). Valdosta, GA. Retrieved from http://www.edpsycinteractive.org/topics/co gnition/bloom.html

IACBE. (2014). Bloom's Taxonomy of Educational Objectives and Writing Intended Learning Outcomes Statements. USA.

Konita, M., Sugiarto, \& Rochmad. (2017). Analysis of Students Ability on Creative Thinking Aspects in terms of Cognitive Style in Mathematics Learning with CORE Model Using Constructivism Approach. Unnes Journal of Mathematics Education, 6(1), 63-70. https://doi.org/10.15294/ujme.v6i1.12496

Munzenmaier, C., \& Rubin, N. (2013). PERSPECTIVES BLOOM'S TAXONOMY: What's Old Is New Again. (C. Holcombe, Ed.). The eLearning Guild. Retrieved from www. e L e a r n i n gGu i 1 d. c om

Nuha, M. A., Waluya, S. B., \& Junaedi, I. (2018). Mathematical Creative Process Wallas Model in Students Problem Posing with Lesson Study Approach. International Journal of Instruction, 11(2), 527-538. Retrieved from https://doi.org/10.12973/iji.2018.11236a

O’Neill, G., \& Murphy, F. (2010). Guide to Taxonomies of Learning. In Assessment. Retrieved from www.ucd.ie/teaching

Potter, M. K., \& Kustra, E. (2012). A Primer on Learning Outcomes and the SOLO Taxonomy.

Utami, A. F., Masrukan, \& Arifudin, R. (2014). Meningkatkan Kemampuan Berpikir Kreatif Siswa Melalui Pembelajaran Model Taba Berbantuan Geometer' s Sketchpad. Jurnal Kreano, 5(1), 63-72.

Warda, A. K., Mashuri, \& Amidi. (2017). The Effectiveness of SSCS Learning Model with KNWS Strategy towards Mathematical Creative Thinking Ability and Self Confidence of Students. Unnes Journal of Mathematics Education, 6(3), 308-317. Retrieved from http://journal.unnes.ac.id/sju/index.php/ujm e

Wijaya, L., Rochmad, \& Agoestanto, A. (2016). Analisis Kemampuan Berpikir Kreatif Matematis Siswa SMP Kelas VII Ditinjau dari Tipe Kepribadian. Unnes Journal of Mathematics Education, 5(2), 84-91. Retrieved from http://journal.unnes.ac.id/sju/index.php/ujm e 